Atualidades de Pesquisa

\title{
FORMAÇÃO DOCENTE E PSICANÁLISE: ANÁLISE DA POSIÇÃO SUBJETIVA DOS PROFESSORES NO DESENVOLVIMENTO PROFISSIONAL
}

Tese de doutorado no Programa de Pós-Graduação em Psicologia da Pontifícia Universidade Católica de Minas Gerais

\author{
Autora \\ Cláudia Rodrigues Fernandes \\ Orientadora \\ Profa. Dra. Ilka Franco Ferrari \\ (Pontifícia Universidade Católica de Minas Gerais)
}

Banca examinadora

Banca examinadora: Prof. Dr. Marcelo Ricardo Pereira (co-orientador Universidade Federal de Minas Gerais), Profa. Dra. Margareth Diniz (Universidade Federal de Minas Gerais), Prof. Dra. Maralice Neves (Universidade Federal de Minas Gerais), Prof. Dra. Mônica Maria Farid Rahme (Universidade Federal de Minas Gerais), Prof. Dr. Dieso Bolaños (Centro Federal de Educação Tecnológica de Minas Gerais) 
$\mathbb{N}$

ão seria exagero afirmar que, hoje, mais do que nunca, a figura do professor encontra-se na berlinda. O poder público discute e teoriza sobre o processo formativo na perspectiva da estruturação dos programas, cursos e capacitações oferecidas aos docentes. No entanto, parece difícil ao discurso educacional perceber o que o professor faz com isso. A reflexão sobre o processo de formação profissional, sob o ponto de vista do sujeito, parece ainda precária. Esta tese investiga de que modo a profissão e a subjetividade docentes são afetadas pelas ações de intervenção do Programa de Intervenção Pedagógica (PIP), implementado pelo poder público em Minas Gerais. Adotamos como referencial teórico-prático a psicanálise. Trabalhamos com as concepções de Sigmund Freud e de Wilfred Bion. A relação com o saber foi nosso operador de leitura para analisar o vínculo do professor com a formação continuada e a prática docente. Para tanto, trabalhamos com pesquisa-intervenção de orientação clínica, que opera com os processos psíquicos, sobretudo inconscientes, nas situações profissionais estudadas. Privilegiamos a observação clínica do professor no contexto de sua prática profissional, a entrevista de orientação clínica e o espaço coletivo de fala. Possibilitamos com a utilização de tais dispositivos apreender o sujeito nas múltiplas formas de apresentar sua subjetividade, abrindo espaços de fala individual e coletiva onde possam emergir suas singularidades discursivas, como também em ato, na observação de sua prática. Ao final do estudo, tivemos poucos indícios de que a formação continuada na escola estudada tenha significado uma mudança subjetiva do professor em sua relação com a prática e o saber. Concluímos que esse modo de subjetivação pouco favoreceu um enfrentamento da dor de existir que pode conduzir à transformação de ideias e ativação do pensamento. 